\title{
Morphological and Strength Properties of Tanjung Bin Coal Ash Mixtures for applied in Geotechnical Engineering Work
}

\author{
Abd. Rahim Awang ${ }^{1}$, Aminaton Marto ${ }^{2}$ and Ahmad Maher Makhtar ${ }^{3}$ \\ Civil Engineering Department,Universiti Teknologi Malaysia 81310 Skudai, Johor Baharu, Malaysia \\ Email :'abdulrahimawang@yahoo.co.uk,2aminaton@utm.my,3amahir@utm.my
}

\begin{abstract}
In Malaysia, coal has been used as a raw material to generate electricity since 1988. In the past, most of the wastage of coal burning especially the bottom ash was not managed properly as it was dumped in the waste pond and accumulated drastically.This paper focuses on some properties of coal ash mixtures (fly ash and bottom ash mixtures) from Tanjung Bin power plant. The characteristics studied were morphological properties, compaction behaviour and strength properties. Strength properties of coal ash mixtures are carried out by conducting direct shear test and unconfined compression test. Besides, morphology and mineralogy of coal ash mixtures are studied using scanning electron microscope (SEM) and $x$-ray diffraction (XRD). The coal ash mixtures were compacted at $95 \%$ of maximum dry density, sealed and cured for 0,14 , and 28 days before they were analysed for shear strength, morphological and mineralogical analyses. The shear strength of coal ash mixtures varied depending on the fly ash compositions. The maximum shear strength was obtained at mixture with 50\%FA: 50\%BA and the value increased with curing periods. The friction angle obtained ranged from $27^{\circ}$ to $37^{\circ}$. Morphological analysis showed that the number of irregular shaped particles increased confirming change in material type with curing period. From mineralogical analysis, the crystalline compounds present in Tanjung Bin coal ash were Mullite, Quartz, Calcium Phosphide, Calcite, Cristobalite and Hematite. It can be concluded that the coal ash mixtures can advantageously be applied in the construction of embankments, roads, reclamation and fill behind retaining structures.
\end{abstract}

Keywords — Coal ash mixtures; Fly ash; Bottom ash; Morphological; Shear strength

\section{INTRODUCTION}

Every year, the coal fired power plant produced large volume of coal ash which are fly ash and bottom ash over the world. Malaysia also is not excepting as a producer of large volume of fly ash and bottom ash. Even though there is no report about the producing of coal ash annually in Malaysia, but basically, there is about $10 \%$ of total weight of the coal burned produces ash [4]. Use of coal ash in construction projects requiring large material volumes, such as highway embankment construction, back fill, soil improvement etc. may offer an attractive alternative to recycle this materials. Besides that, using large volume of the coal ash in geotechnical application is a highly promising solution to the disposal problem.

However, from literature studies, it is observed that there is limited investigation on coal ash in Malaysia. Although there are a lots of studied related to the properties of coal ash, but the investigation about the local coal ash is very limited. Therefore, it is necessary to provide the information based on the laboratory evaluation of the locally available coal ash especially on the coal ash mixtures between fly ash and bottom ash. Then, the findings of this study will help the coal fired power plant companies to overcome the disposal problem and will be useful to introduce the coal ash mixture as new material in geotechnical engineering work.

The main purpose of this study is to find out whether the coal ash mixtures can be used as a new material in geotechnical engineering work. Thus, the objectives of this study were to determine the mineralogical properties of coal ash mixtures and to determine the compaction behavior of different proportion of coal ash mixtures. Also, to determine the morphological and shear strength properties of $95 \%$ compacted coal ash mixtures with time.

\section{LITERATURE REVIEW}

Numerous studies have been completed in which the engineering properties and the physical and morphological characteristic of fly ash, bottom ash and coal ash mixtures were determined in the laboratory. [9] investigated the specific gravity values of fly ash and bottom ash from Wabash River Plant is 2.30 and 2.32 respectively and from A. B. Brown plant is 2.81 and 2.62 respectively. However, [10] investigated that the specific gravity values of fly ash and bottom ash from Tanjung Bin power plant is 2.30 and 1.99 respectively. [6] stated that the specific value is 
depending on the chemical composition especially the amount of iron oxide and the particle structure.

[10] investigated majority of the sizes fly ash is occurred in a range from $0.03 \mathrm{~mm}$ to $0.001 \mathrm{~mm}$ this can graded as mostly fine silt to fine sand sizes. And for bottom ash, their sizes ranging from fine gravel to fine sands sizes and the majority sizes occurred in a range between $10 \mathrm{~mm}$ and $0.075 \mathrm{~mm}$. [10] provided that the shapes of the gradation curves of ash mixtures became well graded with increasing bottom ash content in the ash mixtures.

The study made by [9] on the various mixtures of coal ash show that, as the fly ash content increased from $50 \%$ to $100 \%$, the maximum dry unit weight decreased, whereas the optimum water content increased. Overall the values of maximum dry unit weight of ash were found to be lower than those of typical compacted soils.

[9] investigated the fly ash particles were rounded, spherical in shape and their surfaces appeared to be smooth. Different to the bottom ash particles because it was angular and irregular in shape and had rough, gritty surface textures. Both of fly ash and bottom ash has particle agglomerations which ranged from lightly cemented to strongly bond. According to [10], after curing period, the number of irregular shaped particles is increased and particle size also increased for fly ash. This is due to the pozzolanic reaction has occurred. For bottom ash, compacted specimen is tested and after curing time fine fractions of shattered and irregular bottom ash particles are predominant.

[7] investigated the hematite, quartz, lime and anhydrite are the major crystalline found in coal fly ash from XRD analysis. He also stated that the gehlenite and melilite are present in coal fly ash. According to [5] , the main components of the fly ash are the glass aluminium-silicate matrix, mullite, quartz and magnetite. A similar composition was obtained for bottom ash, with a higher content of magnetite.

The difference of shear strength depends on granular size because smaller size of soil particle will easily overcome the interlocking between particles while it is in friction rather than coarser particle of soil. Other than that, the shape of granular soil will also affect the total of shear strength of the soil. Angular textures of the particles will produce great interlocking features between the soil particle thus result in higher shear strength rather than rounded particles of granular. For all ash mixtures tested have similarity peak friction angel with typically sand ranging from $29^{\circ}$ to $37^{\circ}$ [8].

\section{METHODOLOGY}

\section{A. Preparation of Sample}

Coal ash sample used in this study were extracted from Tanjung Bin power plant, Pontian, Johor (fig. 1). Firstly, the fly ash and bottom ash sample obtained is oven dry (fig.2). After oven dried, the samples are sieve with 2.00 $\mathrm{mm}$ sieve size. Then, the fly ash and bottom ash are mix together with mixture proportion are $0 \%, 30 \%, 50 \%, 70 \%$, $90 \%$ and $100 \%$ of fly ash and measured by weight of total mixtures. The coal ash mixtures samples were stored inside plastic bag to maintain their dry condition. The specimens used for direct shear test, unconfined compression test
(UCT), morphology and mineralogy testing will be based on the compacted sample with moisture content at $95 \%$ maximum dry density and the specimens were cured inside plastic bag to maintain their moisture content condition for 14 and 28 days. All curing samples were stored into the curing tank.

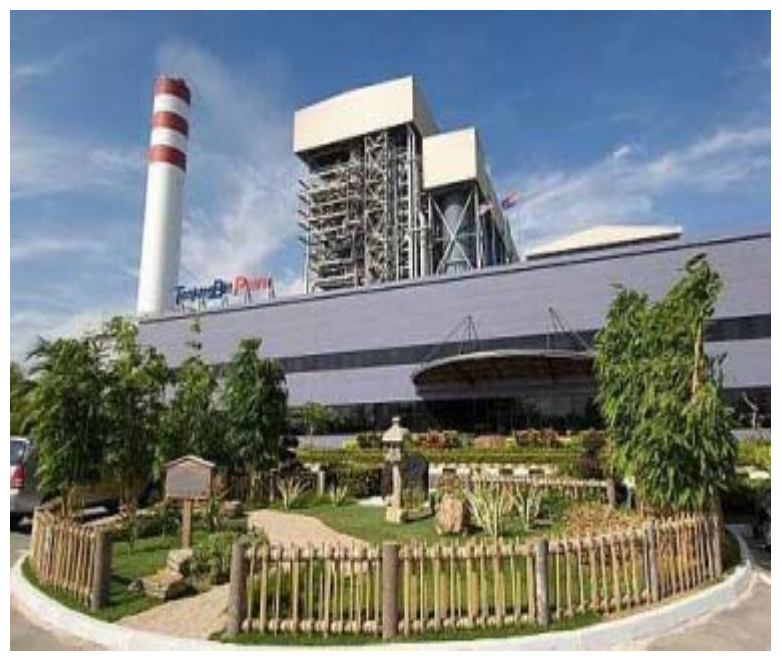

Fig.1 Specific Location of Tanjung Bin Power Plant, Johor (Muhardi et al., 2010)

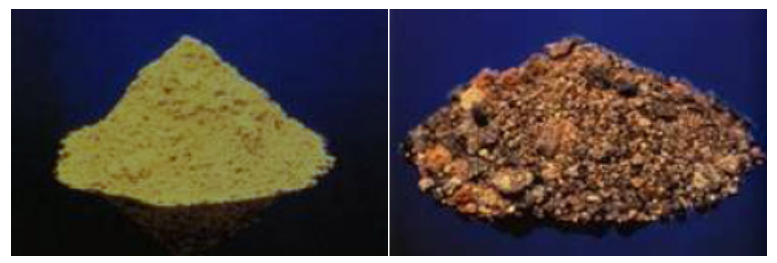

Fig.2 Samples of Tanjung Bin Coal Ash

\section{B. Laboratory Works}

Laboratory works consist of test on compaction, morphology and strength properties of coal ash mixtures (Table 1). The compaction test of coal ash mixtures are carried out to determine the compaction behavior. After that, the morphological and mineralogical properties of coal ash mixtures are carried out consisting of microscopic examination (SEM) and X-ray diffraction test (XRD). Last, the strength properties of coal ash mixtures is carried out which are direct shear test and unconfined compression test (UCT).

TABLE I

\begin{tabular}{|c|c|c|c|}
\hline Test name & Standard used & $\begin{array}{c}\text { Number } \\
\text { test }\end{array}$ & Notes \\
\hline Compaction test & BS 1377-4:1990 & 60 & $\begin{array}{c}10 \text { samples of } \\
\text { each mixtures }\end{array}$ \\
\hline $\begin{array}{c}\text { Microscopic } \\
\text { Examination } \\
\text { (SEM)* }\end{array}$ & - & 18 & $\begin{array}{c}\text { At } 0,14 \text {, and 28 } \\
\text { days curing period }\end{array}$ \\
\hline $\begin{array}{c}\text { X-ray } \\
\text { (XRD)* }\end{array}$ & - & 18 & $\begin{array}{c}\text { At } 0,14 \text {, and 28 } \\
\text { days curing period }\end{array}$ \\
\hline $\begin{array}{c}\text { Direct shear test } \\
\text { Unconfined } \\
\text { compression test } \\
\text { (UCT) }\end{array}$ & BS 1377-7:1990 & 18 & $\begin{array}{c}\text { At 0, 14, and 28 } \\
\text { days curing period }\end{array}$ \\
\hline
\end{tabular}




\section{Data Analysis}

Results gained from each test were recorded in form of table and graph to identify the trend of the collected data compared to the previous study related on fly ash and bottom ash mixtures. After that, the recorded data were analysed to determine the morphological properties and strength properties of the different mixtures.

\section{RESULT AND ANALYSIS}

\section{A. Compaction Test}

Table 2 shows the maximum dry density and optimum moisture content of compacted coal ash mixtures. The results show that, as the fly ash composition increased from $50 \%$ to $100 \%$, the maximum dry density decreased, while the optimum moisture content increased. However, this results show reversed pattern as the fly ash composition increased from $0 \%$ to $50 \%$. This is because at a certain level of fly ash content, the bottom ash particles may be completely separated, floating in a fly ash matrix. Besides that, the gradations of the ash mixtures varying with different mixture ratios also explain the change in dry density. Increasing bottom ash content in coal ash mixtures leads to the increasingly more well graded size distribution, which allows the fly and bottom ash particles to pack more closely and hence, increased the dry density.

TABLE II

MAXIMUM DRY DENSITY AND MOISTURE CONTENT OF COMPACTED COAL ASH MIXTURES

\begin{tabular}{|c|c|c|}
\hline $\begin{array}{c}\text { Fly Ash } \\
\text { composition } \\
(\%)\end{array}$ & $\begin{array}{c}\text { Maximum dry } \\
\text { density } \\
\left(\mathrm{Mg} / \mathrm{m}^{3}\right)\end{array}$ & $\begin{array}{c}\text { Optimum moisture } \\
\text { content }(\%)\end{array}$ \\
\hline 0 & 1.140 & 24.0 \\
\hline 30 & 1.574 & 14.7 \\
\hline 50 & 1.637 & 15.0 \\
\hline 70 & 1.620 & 16.7 \\
\hline 90 & 1.581 & 17.80 \\
\hline 100 & 1.568 & 19.0 \\
\hline
\end{tabular}

\section{B. Microscopic Examination (SEM)}

From SEM analysis, the SEM micrograph of the coal ash mixtures particles from Tanjung Bin power plant shown in Figure 3, Figure 4 and Figure 5 at 0 day, 14 days and 28 days curing periods, respectively. The results show that the $0 \%$ FA mixture, the particles were angular and irregular in shape and had rough, gritty surface textures. The surfaces of the particles also free of dust, clean and shiny. However, as a fly ash composition increased from $0 \%$ to $100 \%$, the angular and irregular shapes were decreased and replaced by rounded and spherical in particles shape. This is because, the fly ash is well rounded, spherical in shapes, round glassy spheres, number of irregular shaped particles and their surface appear to be very smooth. As the curing age of specimen increases, the particle size also increases due to the pozzolanic reaction hence, the number of irregular shaped particles increases. Besides that, there are also some agglomerates bonded particles formed when the curing time increased due to the crystal growth.

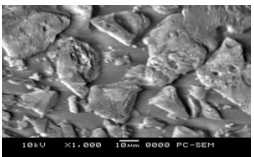

(a)

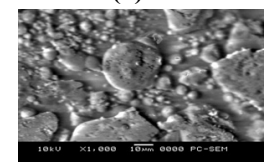

(d)

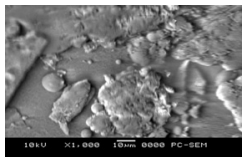

(b)

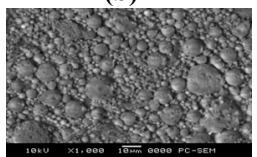

(e)

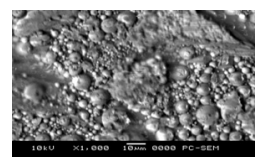

(c)

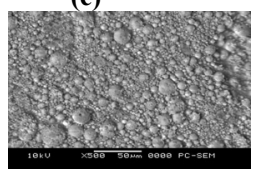

(f)
Fig.3 SEM micrograph of coal ash mixtures particles from Tanjung Bin power plant (0 day)

(Magnification $\times 1000$ ), (a) $0 \% \mathrm{FA}$; (b) $30 \% \mathrm{FA}$; (c) $50 \% \mathrm{FA}$; (d) $70 \% \mathrm{FA}$; (e) $90 \% \mathrm{FA}$; (f) $100 \% \mathrm{FA}$

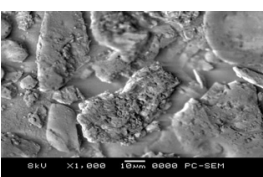

(a)

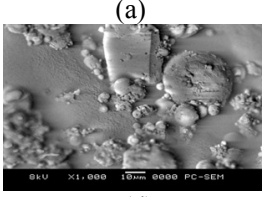

(d)

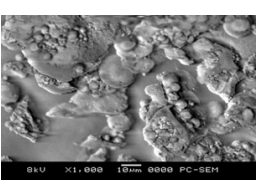

(b)

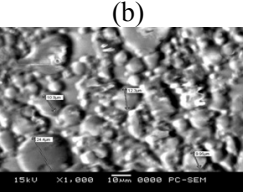

(e)

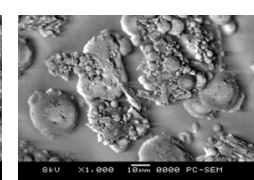

(c)
Fig. 4 SEM micrograph of coal ash mixtures particles from Tanjung Bin power plant (14 days)

(Magnification $\times 1000$ ), (a) $0 \% \mathrm{FA}$; (b) $30 \% \mathrm{FA}$; (c) $50 \% \mathrm{FA}$; (d) $70 \% \mathrm{FA}$; (e) $90 \% \mathrm{FA}$; (f) $100 \% \mathrm{FA}$

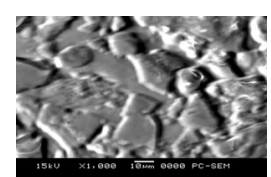

(a)

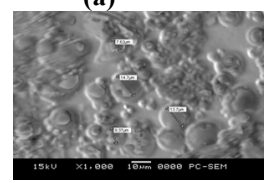

(d)

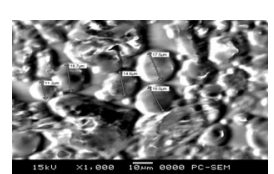

(b)

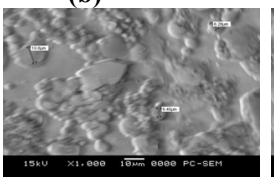

(f)

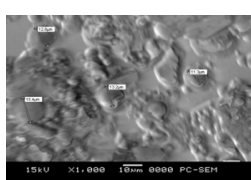

(c)

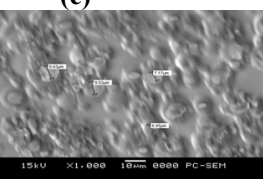

(g)
Fig.5 SEM micrograph of coal ash mixtures particles from Tanjung Bin power plant (28 days)

(Magnification $\times 1000$ ), (a) $0 \% \mathrm{FA}$; (b) $30 \% \mathrm{FA}$; (c) $50 \% \mathrm{FA}$; (d) $70 \% \mathrm{FA}$; (e) $90 \% \mathrm{FA}$; (f) $100 \% \mathrm{FA}$

\section{X-Ray Diffraction (XRD)}

Table 3 shows the summarized results of XRD analysis of coal ash mixtures with curing time. The results show that at 0 day curing period, crystalline compounds present in coal ash mixtures of $0 \%$ to $50 \%$ fly ash content were Mullite, Quartz, Calcium Phosphide, Calcite, Cristobalite and Hematite. The same compounds exist in $70 \%$ to $100 \%$ of fly ash content except for Cristobalite. However, at 100\% fly ash content the Calcium Phosphide also could not be traced.

\section{E. Mechanical Properties of Ash Mixtures}

Standard compaction, hydraulic conductivity, onedimensional compression, and triaxial tests were performed 
on the fly/bottom ash mixtures with fly ash contents of 0,30 , 50, 70, 90 and 100\%. The particles coarser than the No. 4 sieve $(2.00 \mathrm{~mm})$ were used as bottom ash when preparing the mixtures.

\section{F. Standard Compaction test}

Standard compaction tests were performed following (BS 1377-4:1990). Premeasured quantities of fly ash and bottom ash were mixed slowly by hand at first, and then water was sprayed on gradually while the mixing was continued in a mortar mixer. Samples were then compacted in a $38 \mathrm{~mm}$. diameter mold.

\section{G. Hydraulic Conductivity}

The hydraulic conductivity of the ash mixtures was measured by falling head tests using a rigid-wall compaction-mould permeameter, as described by (BS 13771:1990). Each ash mixture was compacted in the mould permeameter to $95 \%$ of the maximum density obtained from the standard Proctor compaction test (i.e., to a relative compaction $\mathrm{R}=95 \%$ ). The compaction moisture content was maintained at approximately optimum for the standard effort.

\section{H. One-Dimensional Compression}

One-dimensional compression tests were performed on samples prepared at their optimum water content, and compacted using a standard manual rammer to $\mathrm{R}=95 \%$ in a split mold with a diameter of $72 \mathrm{~mm}$ (2.8 in.) and a height of $55 \mathrm{~mm}$ (2.2 in.). The tests were conducted according to the normal consolidation test procedure described in (BS 1377-7:1990). The compacted sample was carefully trimmed and placed in a consolidation ring with a diameter of $64 \mathrm{~mm}$ (2.5 in.) and a height of $25 \mathrm{~mm}$ (1.0 in.). The specimen was soaked for 24 hour before compression, and then loaded incrementally to a maximum vertical stress of $1,600 \mathrm{kPa}$.

\section{RESUlt AND Discussions}

\section{A. Gradation}

Fig. 1 shows the grain size distributions for each fly ash and bottom ash used, as well as their respective mixtures. Generally, the fly ash was well graded, ranging from mostly silt to fine sand sizes. A majority of the sizes occurred in a range between 0.001 and $0.06 \mathrm{~mm}$. Fig. 1 suggests that the Tanjung Bin fly ash had more silt size particles while bottom ash sizes occurred in a range between 0.03 and 2.00 $\mathrm{mm}$. The grain size distributions for fly/bottom ash mixtures were well graded, ranging from mostly silt to fine sand sizes. A majority of the sizes occurred in a range between 0.001 and $1.25 \mathrm{~mm}$. Fig. 1 also suggests that the mixtures of $(30 \%$ to $90 \%$ fly ash by weight) Tanjung bin power plant had more silt size particles. The shapes of the gradation curves indicated that the size distributions became better graded with increasing bottom ash content in the ash mixtures. The ash materials tested in the present research were classified by the Unified Soil Classification System; these classifications, including basic grain size indices, are given in Table 1.

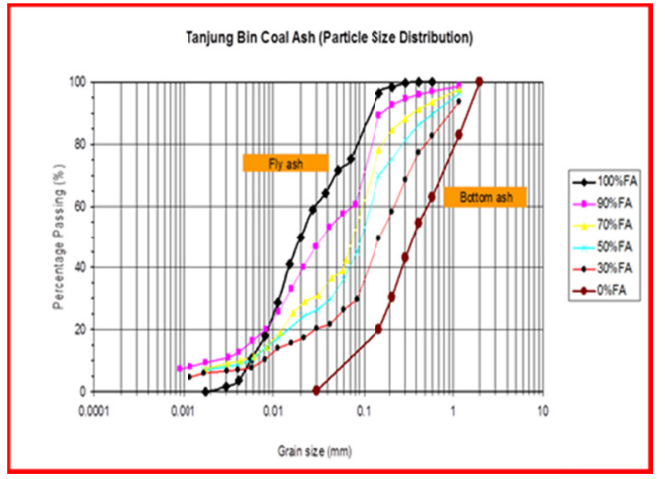

Fig. 6 : Grain size distribution Tanjung Bin coal ash

TABLE III

THE VALUE OF Cu AND Cc COAL ASH MIXTURES

\begin{tabular}{|c|c|c|}
\hline $\begin{array}{c}\text { Coal ash } \\
\text { mixtures }\end{array}$ & $\begin{array}{c}\text { Coefficient of } \\
\text { uniformity }(\mathrm{Cu}= \\
\left(\mathrm{D}_{60} /\left(\mathrm{D}_{10}\right)\right.\end{array}$ & $\begin{array}{c}\text { Coefficient of } \\
\text { curvature }(\mathrm{Cc}= \\
\left(\mathrm{D}_{30}\right)^{2} /\left(\mathrm{D}_{10} \mathrm{x}\left(\mathrm{D}_{60}\right)\right.\end{array}$ \\
\hline $100 \% \mathrm{FA}$ & 5.0 & 1.1 \\
\hline $90 \% \mathrm{FA}$ & 26.7 & 1.19 \\
\hline $70 \% \mathrm{FA}$ & 23.8 & 1.78 \\
\hline $50 \% \mathrm{FA}$ & 21.8 & 2.46 \\
\hline $30 \% \mathrm{FA}$ & 27.5 & 3.65 \\
\hline $0 \% \mathrm{FA}$ & 7.4 & 1.09 \\
\hline
\end{tabular}

\section{B. Morphology Characteristic}

Fig. 2 shows SEM photomicrographs of the fly/bottom ash mixtures particles from Tanjung Bin Pontian. In general, fly ash particles were well rounded, spherical in shape, and their surfaces appeared to be smooth. Some particles were very small (less than $1 \mathrm{~mm}$ ). Some particles were shaped as hollow spheres with thin walls. A distinct morphological difference between the fly ashes from the two ash sources was the extent of the agglomeration of particles, which appeared to be more prevalent in the Brown plant fly ash. Fig. 3 displays LM photomicrographs of bottom ash particles. In terms of the shape and surface characteristics of the particles, bottom ash was quite different from fly ash. Bottom ash particles were angular and irregular in shape and had rough, gritty surface textures. The surfaces of the particles were observed to be essentially free of dust, clean and shiny. Some large particles were both internally and externally porous, making the particles more crushable. Some of the popcorn-like particles were crushed even under applied finger pressure. Particle agglomerations were also observed in bottom ash. These agglomerates ranged from lightly cemented to strongly bond.

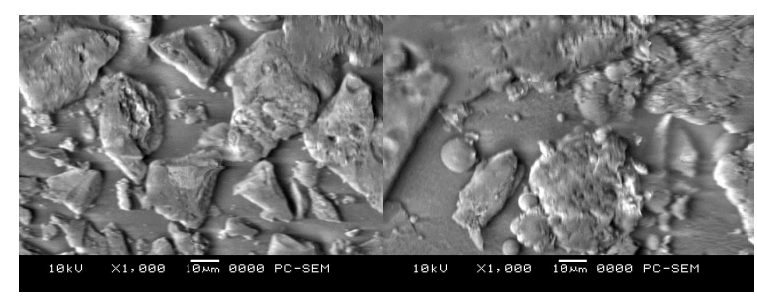

(a)

(b) 


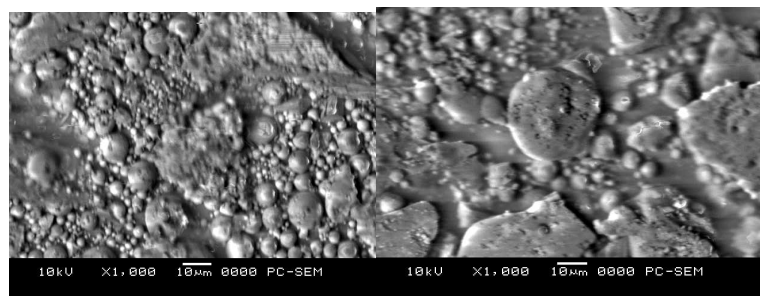

(c)

(d)

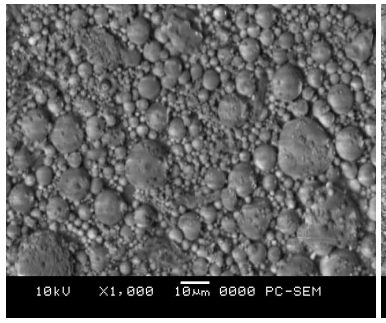

(e)

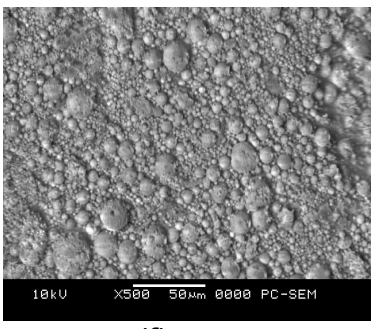

(f)

Fig. 7 : SEM micrograph of coal ash mixtures particles from Tanjung Bin power plant (Magnification $\times 1000$ ), (a) $0 \% \mathrm{FA}$; (b) $30 \% \mathrm{FA}$; (c) $50 \% \mathrm{FA}$; (d) $70 \% \mathrm{FA}$; (e) $90 \% \mathrm{FA}$; (f) $100 \% \mathrm{FAGrain}$ size distribution Tanjung Bin coal ash

\section{Morphology Characteristic}

Table 2, shows the summarized of results of XRD analysis of coal ash mixtures. Results of XRD analysis shows that crystalline compounds present in coal ash mixtures increasing from $0 \%$ to $50 \%$ of fly ash content were Mullite, Quartz, Calcium Phosphide, Calcite, Cristobalite and Hematite. However, Cristobalite does not exist in 70\% to $100 \%$ of fly ash content also the Calcium Phosphide not existed in $100 \%$ FA.

TABLE IV

XRD ANALYSIS OF COAL ASH MIXTURES

\begin{tabular}{|c|c|c|c|c|c|}
\hline \multicolumn{6}{|c|}{ Crystalline Compounds } \\
\hline $0 \% \mathrm{FA}$ & $30 \% \mathrm{FA}$ & $50 \% \mathrm{FA}$ & $70 \% \mathrm{FA}$ & $90 \% \mathrm{FA}$ & $\begin{array}{l}100 \% \mathrm{~F} \\
\mathrm{~A}\end{array}$ \\
\hline $\begin{array}{l}\text { Mullite } \\
\left(3 \mathrm{AI}_{2} \mathrm{O}_{3} .2\right. \\
\left.\mathrm{SiO}_{2}\right), \\
\text { Quartz } \\
\left(\mathrm{SiO}_{2}\right) \text {, } \\
\text { Calcium } \\
\text { Phosph- } \\
\text { de }(\mathrm{CaP}) \text {, } \\
\text { Calcite } \\
\left(\mathrm{CaCO}_{3} \text {, }\right. \\
\text { Cristobali } \\
\text { te and } \\
\text { Hematite }\end{array}$ & $\begin{array}{l}\text { Mullite } \\
\left(3 \mathrm{AI}_{2} \mathrm{O}_{3}\right. \\
\left..2 \mathrm{SiO}_{2}\right) \text {, } \\
\text { Quartz } \\
\left(\mathrm{SiO}_{2}\right) \text {, } \\
\mathrm{Calciu} \\
\mathrm{m} \\
\mathrm{Phosphi} \\
\text {-de } \\
(\mathrm{CaP}) \text {, } \\
\mathrm{Calcite} \\
\left(\mathrm{CaCO}{ }_{3}\right. \\
\text { Cristob } \\
\text { alite } \\
\text { and } \\
\text { Hemati- } \\
\text { te }\end{array}$ & $\begin{array}{l}\text { Mullite } \\
\left(3 \mathrm{AI}_{2} \mathrm{O}_{3}\right. \\
\left..2 \mathrm{SiO}_{2}\right), \\
\text { Quartz } \\
\left(\mathrm{SiO}_{2}\right) \text {, } \\
\mathrm{Calciu} \\
\mathrm{m} \\
\mathrm{Phosphi} \\
\text {-de } \\
(\mathrm{CaP}) \text {, } \\
\mathrm{Calcite} \\
\left(\mathrm{CaCO}{ }_{3}\right. \\
\mathrm{Cristob} \\
\text { alite } \\
\text { and } \\
\text { Hematit } \\
\text {-te }\end{array}$ & $\begin{array}{l}\text { Mullite } \\
\left(3 \mathrm{AI}_{2} \mathrm{O}_{3}\right. \\
\cdot \\
\left.2 \mathrm{SiO}_{2}\right) \text {, } \\
\mathrm{Quartz}\left(\mathrm{SiO}_{2}\right) \text {, } \\
\mathrm{Calciu} \\
\mathrm{m} \\
\mathrm{Phosphi} \\
\text { de } \\
(\mathrm{CaP}) \text {, } \\
\mathrm{Calcite} \\
(\mathrm{CaCO} \\
) \text { and } \\
\text { Hemati } \\
\text {-te. }\end{array}$ & $\begin{array}{l}\text { Mullite } \\
\left(3 \mathrm{AI}_{2} \mathrm{O}_{3}\right. \\
\left..2 \mathrm{SiO}_{2}\right) \text {, } \\
\text { Quartz } \\
\left(\mathrm{SiO}_{2}\right) \text {, } \\
\text { Calciu } \\
\mathrm{m} \\
\text { Phosphi } \\
\text {-de } \\
(\mathrm{CaP}) \text {, } \\
\text { Calcite } \\
(\mathrm{CaCO} 3 \\
) \text { and } \\
\text { Hemati- } \\
\text { te }\end{array}$ & $\begin{array}{l}\text { Mullite } \\
\left(3 \mathrm{AI}_{2} \mathrm{O}_{3}\right. \\
\left.2 \mathrm{SiO}_{2}\right) \text {, } \\
\text { Quartz } \\
\left(\mathrm{SiO}_{2}\right) \text {, } \\
\mathrm{Calcite} \\
\left(\mathrm{CaCO}_{3}\right. \\
\text { ) and } \\
\text { Hemati } \\
\text {-te. }\end{array}$ \\
\hline
\end{tabular}

\section{Morphology Characteristic}

The chemical composition of the coal ash mixtures samples was investigated using XRF analysis. The percentage of the chemical contents for Tanjung Bin coal ash mixtures are given in table 3 . The major of contents of Tanjung Bin coal ash mixtures (reported as oxides) were silica, alumina, iron and calcium oxide. Smaller percentage of magnesium, kalium, barium, potassium, sodium, and titanium oxides were also found. As can be seen from this table, Tanjung Bin coal ash mixtures has relatively low lime $(\mathrm{CaO})$ content, less than 10 percent. According to [10], class of Tanjung Bin fly ash is class F which is ash is typically obtained from bituminous and anthracite coals and consists primarily of an alumina silicate glass, with quartz, mullite, and magnetite also present.

TABLE V

CHEMICAL CONTENT OF TANJUNG BIN COAL ASH MIXTURES

\begin{tabular}{|l|l|l|l|l|l|l|}
\hline \multirow{2}{*}{$\begin{array}{l}\text { Chemical } \\
\text { contents }\end{array}$} & $\mathbf{0 \%}$ & $\mathbf{3 0} \%$ & $\mathbf{5 0} \%$ & \multicolumn{7}{|c|}{$\mathbf{7 0 \%}$} & $\mathbf{9 0 \%}$ & $\mathbf{1 0 0 \%}$ \\
\cline { 2 - 7 } Concentrations (\%) \\
\hline $\mathrm{CO}_{2}$ & 0.10 & 0.10 & 0.10 & 0.10 & 0.10 & 0.10 \\
\hline $\mathrm{SiO}_{2}$ & 46.60 & 46.70 & 46.80 & 46.90 & 46.90 & 47.10 \\
\hline $\mathrm{Al}_{2} \mathrm{O}_{3}$ & 26.10 & 27.60 & 28.50 & 28.90 & 29.60 & 30.00 \\
\hline $\mathrm{Fe}_{2} \mathrm{O}_{3}$ & 12.40 & 10.40 & 9.31 & 8.52 & 7.65 & 7.34 \\
\hline $\mathrm{CaO}$ & 8.31 & 7.95 & 7.73 & 7.69 & 7.48 & 7.21 \\
\hline $\mathrm{TiO}_{2}$ & 1.84 & 1.83 & 1.80 & 1.84 & 1.86 & 1.83 \\
\hline $\mathrm{K}_{2} \mathrm{O}$ & 1.34 & 1.43 & 1.45 & 1.51 & 1.53 & 1.62 \\
\hline $\mathrm{MgO}_{2}$ & 1.26 & 1.29 & 1.31 & 1.41 & 1.53 & 1.52 \\
\hline $\mathrm{P}_{2} \mathrm{O}_{5}$ & 0.62 & 1.02 & 1.23 & 1.32 & 1.32 & 1.37 \\
\hline $\mathrm{Na}_{2} \mathrm{O}$ & 0.62 & 0.57 & 0.56 & 0.64 & 0.70 & 0.72 \\
\hline $\mathrm{SO}_{3}$ & 0.30 & 0.48 & 0.54 & 0.50 & 0.50 & 0.49 \\
\hline $\mathrm{SrO}$ & 0.19 & 0.23 & 0.26 & 0.29 & 0.31 & 0.32 \\
\hline
\end{tabular}

\section{E. Specific Gravity}

The values of specific gravity of coal ash mixtures are summarized in table 4 and fig.3. These values ranged from 2.19 to 2.36 . The wide range in specific gravity can be attributed to two factors: (1) Chemical composition, and (2) presence of hollow fly ash particles or particles of bottom ash with porous or vesicular textures. The low specific gravities of Tanjung Bin coal ash mixtures are explained by their low iron oxide contents and, conversely, the high specific gravities of Tanjung Bin coal ash mixtures by their high iron oxide contents. Different amounts of hollow particles present in fly ash also cause a variation in apparent specific gravity. Obviously, a fly ash containing a large percentage of hollow particles would have a lower apparent specific gravity than one with mostly solid particles. In fact, the two factors affecting the specific gravity of fly ash may be related. [9] examined the chemical compositions of hollow and solid fly ash particles separately, and the data revealed that hollow-particle fly ash had significantly lower iron content $(4.5 \%)$ than solid-particle fly ash $(25.1 \%)$. The apparent specific gravity of bottom ash is also affected by the porosity of its particles. Comparing the specific gravities reported in Table 2 for fly ash composition, the bottom ash has a highest specific gravity than the fly ash, and indicates that slightly higher iron content may be present in the bottom ash. This may be due to the presence of highly porous popcorn-like bottom ash particles.

TABLE VI

SPECIFIC GRAVITY OF TANJUNG BIN COAL ASH MIXTURES

\begin{tabular}{|c|c|}
\hline $\begin{array}{c}\text { Fly Ash Composition } \\
(\mathbf{\%})\end{array}$ & Specific Gravity \\
\hline 0 & 2.36 \\
\hline 30 & 2.34 \\
\hline 50 & 2.33 \\
\hline 70 & 2.23 \\
\hline 90 & 2.20 \\
\hline 100 & 2.19 \\
\hline
\end{tabular}




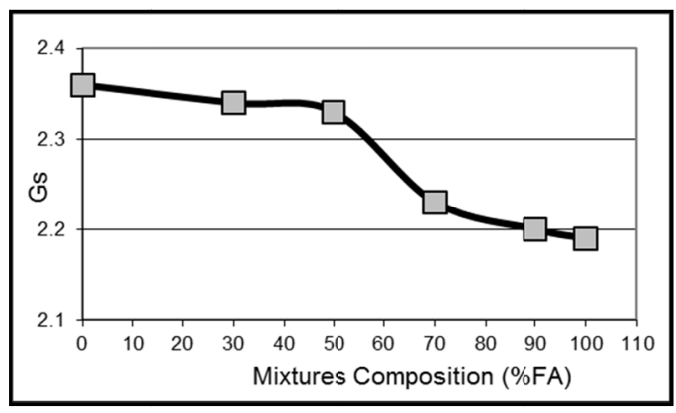

Fig. 8 A graph of Mixtures composition versus Specific Gravity

\section{F. Compaction Behaviour}

Table 5 shows the compacted dry unit weight versus the water content curves of the ash mixtures. The results show that, as the fly ash composition increased from $50 \%$ to $100 \%$, the maximum dry density decreased, while the optimum moisture content increased. However, this results show reversed pattern as the fly ash composition increased from $0 \%$ to $50 \%$. This is because at a certain level of fly ash content, the bottom ash particles may be completely separated, floating in a fly ash matrix. Besides that, the gradations of the ash mixtures varying with different mixture ratios also explain the change in dry density. Increasing bottom ash content in coal ash mixtures leads to the increasingly more well graded size distribution, which allows the fly and bottom ash particles to pack more closely and hence, increased the dry density.

From another perspective, the gradations of the ash mixtures varying with different mixture ratios also explain the change in dry unit weight. The addition of bottom ash to fly ash leads to increasingly more well-graded size distributions, which allows the fly and bottom ash particles to pack more closely, resulting in the increase in maximum dry density. The higher $\mathrm{w}_{\text {opt }}$ associated with higher $\mathrm{F}$ values follows from the need to release the capillary tension from the greater exposed surface of the finer fly ash particles. Some bottom ash particle crushing during compaction may have contributed to the increase in the maximum dry density of ash mixtures. Compared with the maximum dry density of compacted soils, the maximum dry density values of ash mixtures tended to be lower than those of soils, which range typically from 1.7 to $2.0 \mathrm{kN} / \mathrm{m}^{3}$ (U.S. Navy 1986).

TABLE VII

MAXIMUM DRY DENSITY AND MOISTURE CONTENT OF COMPACTED COAL ASH MIXTURES

\begin{tabular}{|c|c|c|}
\hline $\begin{array}{c}\text { Mixtures } \\
\text { Composition }\end{array}$ & $\begin{array}{c}\text { Optimum Water } \\
\text { Content } \mathbf{( \% )}\end{array}$ & $\begin{array}{c}\text { Max. Dry Density } \\
\left(\mathbf{k N} / \mathbf{m}^{\mathbf{3}}\right)\end{array}$ \\
\hline $100 \% \mathrm{FA}$ & 19.0 & 1.568 \\
$90 \% \mathrm{FA}$ & 17.8 & 1.581 \\
$70 \% \mathrm{FA}$ & 16.2 & 1.620 \\
$50 \% \mathrm{FA}$ & 15.0 & 1.637 \\
$30 \% \mathrm{FA}$ & 14.7 & 1.574 \\
$0 \% \mathrm{FA}$ & 24.0 & 1.140 \\
\hline
\end{tabular}

\section{G. Hydraulic Conductivity}

Table 6 and fig.4 shows the values of hydraulic conductivity for compacted ash mixtures with 0 to $100 \%$ fly ash. The measured values varied from $1.47 \times 10^{-6}$ to $2.01 \times 10^{-7} \mathrm{~m} / \mathrm{s}$, indicating a range similar to those of fine sand/silt mixtures or silt. As ash mixtures increased from 0 to $100 \%$, the values of hydraulic conductivity decreased gradually. The larger specific surface of fly ash causes more resistance to flow of water through the voids. [5] performed a series of hydraulic conductivity tests on Indiana bottom ashes. He observed that the fines included in bottom ash had a predominant effect on the permeability, and thus the hydraulic conductivity decreased as the fine contents increased.

TABLE VIII

HYDRAULIC CONDUCTIVITY (k) OF COMPACTED COAL ASH MIXTURES

\begin{tabular}{|c|c|}
\hline Mixtures Composition & Permeability (k m/sec) \\
\hline 100\% Fly ash & $2.01 \times 10^{-7}$ \\
$90 \%$ Fly ash & $2.09 \times 10^{-7}$ \\
$70 \%$ Fly ash & $2.65 \times 10^{-7}$ \\
$50 \%$ Fly ash & $5.82 \times 10^{-7}$ \\
30\% Fly ash & $1.05 \times 10^{-6}$ \\
$0 \%$ Fly ash & $1.47 \times 10^{-6}$ \\
\hline
\end{tabular}

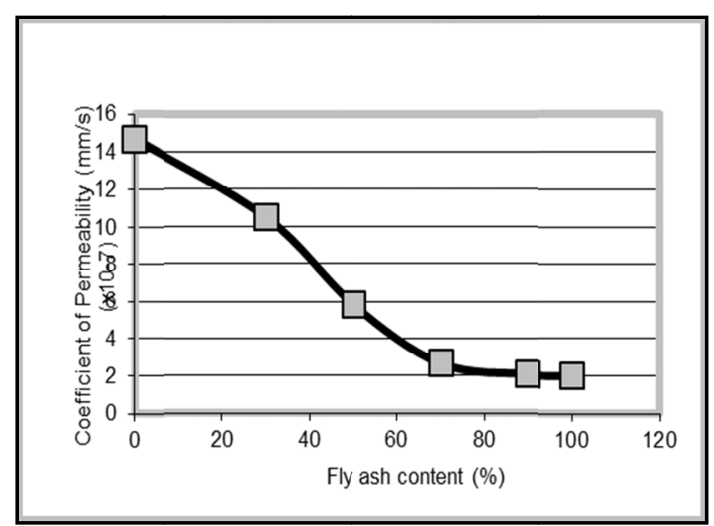

Fig. 9 A graph of Fky Ash content versus Coefficient of Permeability

\section{H. Direct Shear test}

Table 7 shows the summarized of direct shear test results for coal ash mixtures. The results show that, as the fly ash composition increased from $30 \%$ to $100 \%$, the cohesion intercept, $\mathrm{c}$ and friction angle, $\phi$ is decreased. This can be alternatively stated as $\phi$ increasing with increasing bottom ash content. This increase in $\phi$ with bottom ash is primarily due to the angularity of bottom ash particles, which provides higher resistance to particle rearrangement for sustained shearing. The reason is the particle size is increased due to the pozzolanic reaction at the same time as the number of irregular shaped particles also increased and some agglomerates bonded particles are formed.

TABLE IX

DIRECT SHEAR TEST FOR COAL ASH MIXTURES

\begin{tabular}{|c|c|c|}
\hline $\begin{array}{c}\text { Fly Ash } \\
\text { Composition } \\
\mathbf{( \% )}\end{array}$ & $\mathbf{c ~ ( k P a )}$ & $\phi($ Degrees) \\
\hline 0 & 9.89 & 35.98 \\
\hline 30 & 9.41 & 35.06 \\
\hline 50 & 7.14 & 34.78 \\
\hline 70 & 6.39 & 33.45 \\
\hline 90 & 5.28 & 32.14 \\
\hline 100 & 4.38 & 27.12 \\
\hline
\end{tabular}




\section{Unconfine Compression Test (UCT)}

Table 8 shows the summarized results of unconfined compression tests for coal ash mixtures. The results show that, the $50 \%$ of fly ash composition had the highest shear strength compared to the other mixtures. This may be due to the optimum bonded between fly ash and bottom ash particles. The results also show that, without the addition of fly ash, the shear strength seemed to be the lowest because the bottom ash exhibits small cohesive characteristics. In addition, which might be due to the pozzolanic reactions and also some agglomerates bonded particles formed due to the crystal growth.

TABLE X

UNCONFINED COMPRESSION TESTS FOR COAL ASH MIXTURES

\begin{tabular}{|c|c|c|c|c|c|}
\hline $\begin{array}{l}\text { Fly Ash } \\
\text { Compos- } \\
\text { ition (\%) }\end{array}$ & $\begin{array}{c}\text { Cell } \\
\text { pres } \\
\text { sure } \\
(\mathrm{kPa} \\
)\end{array}$ & $\begin{array}{c}\text { Max. } \\
\text { correcte } \\
\mathrm{d} \\
\text { deviator } \\
\text { stress } \\
(\mathrm{kPa})\end{array}$ & $\begin{array}{c}\text { Cumul } \\
\text { a } \\
\text {-tive } \\
\text { strain }\end{array}$ & $\begin{array}{l}\text { Mode } \\
\text { of } \\
\text { failure }\end{array}$ & $\begin{array}{c}\text { Shear } \\
\text { strength } \\
(\mathrm{kPa})\end{array}$ \\
\hline $0 \% \mathrm{FA}$ & \multirow{6}{*}{0.3} & 11 & $1.32 \%$ & \multirow{6}{*}{$\begin{array}{c}\text { Max. } \\
\text { deviat } \\
\text { or } \\
\text { stress } \\
\text { or } \\
\text { max. } \\
\text { allowe } \\
\text { d } \\
\text { strain }\end{array}$} & 6.0 \\
\hline $30 \% \mathrm{FA}$ & & 80 & $3.89 \%$ & & 40.0 \\
\hline $50 \% \mathrm{FA}$ & & 236 & $2.82 \%$ & & 118.0 \\
\hline $70 \% \mathrm{FA}$ & & 114 & $3.41 \%$ & & 57.0 \\
\hline $90 \% \mathrm{FA}$ & & 105 & $2.79 \%$ & & 52.0 \\
\hline $100 \% \mathrm{FA}$ & & 129 & $3.27 \%$ & & 64.0 \\
\hline
\end{tabular}

\section{RESULTS AND DISCUSSIONS}

A variety of tests were performed on fly ash composed of fine, nearly spherical particles ranging in size from silt to fine sand, bottom ash composed of coarse angular particles ranging in size from sand to small gravel, and mixtures of the two. Both fly and bottom ash exhibit some special morphological characteristics that are distinctly different from typical soils. The fly ash particles in this study were mostly hollow spheres with thin walls. Some bottom ash particles had complex pore structures. Also, some of the fly ash or bottom ash particles were agglomerations of finer particles. The morphological characteristics of fly and bottom ash affected their specific gravity, particle strength, and consequently, other mechanical properties to varying degrees.

Fly/bottom ash mixtures (with mixture ratios ranging from $50 \%$ to $100 \%$ fly ash content) were found to exhibit relatively well-defined moisture-density relationships, and the relationships varied with the mixture ratio. However, overall, the values of $\delta_{(\mathrm{d}, \max )}$ of ash mixtures were found to be lower than those of typical compacted soils.

The hydraulic conductivity of compacted ash mixtures were found to decrease slightly with increasing fly ash content. This is primarily due to the increasing specific surface with increasing fines content, which generates more resistance to water flow through voids between particles. The overall range of the values was similar to that of a fine sand/silt mixture or silt.

From a mechanical point of view, the fly/bottom ash mixtures compared favourably with conventional sandy soils. They may be more compressible than typical compacted sands at the same compaction levels, mainly due to the higher crushability of bottom ash. At the low to moderate stress levels expected in typical highway embankments, however, the compressibility of compacted ash mixtures is similar to that of typical compacted sands. Moreover, samples of compacted ash mixtures at a moderately high compaction level (e.g., 95\% relative compaction) exhibited comparable or even higher shear strength than that of compacted sands at similar compaction levels.

In order of decreasing significance, the degree of relative compaction, the confining stress, and the mixture ratio all affect the stress-strain and volumetric behavior of an ash mixture under shearing, and therefore its peak shear strength. Ash mixtures at $95 \%$ relative compaction typically exhibited a behavior similar to that of sandy soils in dense states (i.e., dilatant behaviour), whereas those at $90 \%$ relative compaction resembled sand in loose states. Increasing confining stress decreased dilatancy, and thus decreased peak friction angles. Increasing bottom ash content also tended to decrease dilatancy, primarily due to crushing of bottom ash particles during shearing. At $95 \%$ relative compaction, however, the effect of fly/bottom ash mixture ratio on the peak shear strength was found to be relatively minimal. The values of critical state friction angle of the ash mixtures were found to be in the same range observed for typical sands.

Based on the results obtained in this study, it appears that high volume fly ash mixtures are suitable for use as backfill in embankments construction, if proper design and construction procedures are followed. Prior to use, the materials must pass the appropriate environmental requirements set by state regulatory agencies. If the environmental requirements are satisfied, the fly/bottom ash mixtures can provide fill materials of comparable strength and compressibility to most soils typically used as fill materials, while having the advantage of smaller dry unit weights.

\section{ACKNOWLEDGMENT}

The authors would like to thank the Management of Tanjung Bin Power Plant, Pontian Johor for supplying the coal ash (fly and bottom ash) samples throughout this research works, Ministry of Higher Education, Vote no. Q.J13000.7122.00H33 from Research University Grant, also to Universiti Teknologi Malaysia (UTM) and Universiti Teknologi Tun Hussein Onn (UTHM) for providing the facilities for the laboratory testing.

\section{REFERENCES}

[1] Joseph, and C. Chong. (2005). Report of the Fourth Meeting of The Asean Forum on Coal (AFOC) Council. New World Renaissance Hotel, Makati City, Philippines.

[2] ACAA, (2003). Coal Combustion Product (CCP) Production and Use Survey.Ash at work (Winter/Spring):25.

[3] GAI Consultants, Inc./USIFCAU. 1993 . "Use of coal combustion.by products in highway construction." Prepared for General Assembly of Indiana and the Indiana Department of Transportation in response to House Enrolled Act 1056 and Senate Bill 209.

[4] Huang H.W. (1990). The Use of Bottom Ash in Highway Embankments, Subgrade and Subbases. Joint Highway Research 
Project, Final Report, FHWA/IN/JHRP- 90/4! Purdue University, W.Lafayette, Indiana.

[5] Das. S.K., and Yudhbir. (2005). Geotechnical Characterization of Some Indian Fly Ashes. Journal of Materials in Civil Engineering Vol. 17 No. 5, pp. 546.

[6] Hough, B.K."Basic Soils Engineering.”The Ronald Press Company, NewYork, 1997.

[7] Marto, A., Mahir, A. M., Lee, F. W., Yap, S. L. and Muhardi (2009). Morphology, Mineralogy and Physical Characteristics of Tanjung Bin Coal Ash. Proceedings of 4th International Conference on Recent Advanced in Materials, Minerals and Environment (RAMM)
\& 2nd Asian Symposium on Material \& Processing (ASMP), 1-3 June 2009, Pulau Penang, Malaysia.

[8] Kim, B.J., Yoon, S.M., and Balunaini, U. (2006). Determination of Ash Mixture Properties and Construction of Test Embankment -Part A. Joint Transportation Research Program, Final Report, FHWA/IN/JTRP-2006/24! Purdue University, W. Lafayette, Indiana.

[9] Kim, B., Prezzi, M., and Salgado, R. (2005). "Geotechnical properties of fly and bottom ash mixtures for use in highway embankments." J. Geotech. Geoenviron. Eng., 131(7), 914-924.

[10] Muhardi, Kasim, K.A, Makhtar, A.M, Lee, F.W, and Yap, S.L (2010). "Engineeering Characteristic of Tanjung Bin Col Ash". Vol. 15 [2010], Bunk. K. 